\title{
アポ蛋白 $\mathrm{E} の$ 遺伝的表現型と脂質，アポ蛋白代謝 ${ }^{*}$
}

\author{
今 利 泰 久** 古賀俊逸** 井林 博**
}

\section{I. 目 的}

アポ蛋白はリポ蛋白の構成や代謝に重要な意義 を有していることが知られており，とくに原発性 III 型高脂血症においてはアポEの異常がその病 態発現の重要な因子となっていると考えられてい る1).さらに等電点電気泳動法を用いたアポ Eの isoform の研究以来, この遺伝的表現型とアポ $\mathrm{E}$ および脂質代謝異常との関連性が注目されている. そこでわれわれは健常者を対象としてアポ $\mathrm{E} の$ 遺 伝的表現型の分類を行い，それぞれの血清脂質お よびアポ蛋白濃度を測定したので，これらの成績 について報告する。

\section{II. 対象および方法}

対象は健常者91名で，うち男性は35名，女性は 56名であり，その年龄は18歳から70歳までで，平 均年齢は 38.5 歳であった。 これらの対象より得ら れた早朝空腹時血清 $7 \mathrm{ml}$ から，35,000 rpm $\times 16$ 時間の超遠心操作により VLDL $(\mathrm{d}<1.006 \mathrm{~g} / \mathrm{ml})$ を分離した。この VLDLに 10 倍量の acetone, ethanol 等容液を加え, $-20^{\circ} \mathrm{C}$ にて 4 時間およ び 2 時間の 2 回の脱脂操作を繰り返し,さらに diethyletherにて 1 時間の洗浄操作を行い apo VLDL を得た.この apo VLDL は $-20^{\circ} \mathrm{C} に て$ 保存し, 泳動直前に $10 \mathrm{mM}$ の dithiothreitol と $8 \mathrm{M}$ 尿素を含む, $20 \mathrm{mM}$ Tris-HCl buffer ( $\mathrm{pH}$ 8.6) $200 \mu l$ にて溶解させ，そのうちの $100 \mu l$ を以下 の等電点電気泳動に用いた。

等電点電気泳動 2 は, $8 \mathrm{M}$ 尿素を含む $7.5 \%$ polyacrylamide gel を支持体として行った，am-

* 1984年 6月, 第 16 回日本動脈硬化学会総会において 発表

** 九州大学医学部第三内科 pholite (LKB) は pH 4-6 と pH 3.5-10 のものを $4: 1$ に混和し, ゲルに $2 \%$ の濃度となるように加 えた. ゲルは内径 $0.5 \mathrm{~cm}$, 長さ $10 \mathrm{~cm}$ のガラス管 に高さが $7 \mathrm{~cm}$ となるように作製した。泳動は陽 極液に $10 \mathrm{mM}$ のリン酸溶液を, 陰極液には $20 \mathrm{mM}$ の水酸化ナトリウム溶液を用いて, はじめに $4^{\circ} \mathrm{C}$ にて, $110 \mathrm{~V}, 1$ 時間の prefocusing を行い, 続い て sample および overlayer をのせて $250 \mathrm{~V}, 16$ 時 間の focusing を行った. focusing 終了後, ゲル はガラス管より取り出し，そのまま染色液につけ て 1 晚放置し, その後 $5 \%$ 酢酸溶液を満たした小 試験管に移して保存した。なお染色液は，3.5\% の perchloric acid 溶液に Coomassie Brilliant Blue G-250を $0.04 \%$ となるように溶解したものを使用 した ${ }^{3)}$ (Fig. 1).

アポEのバンドの確認には, 交叉免疫電気泳動 と各バンドの $\mathrm{pI}$ 值の測定を行った. 交叉免疫電 気泳動は, 未染色の等電点電気泳動ゲルをアポ $\mathrm{E}$ 抗体を含む $1 \%$ アガロースゲルの一端に固定し， $4^{\circ} \mathrm{C}$ にて $100 \mathrm{~V}, 16$ 時間の泳動を行った (Fig. 2). この方法により, 各アポEに対応するバンドが同 定できた. pI 值の測定は, 試料を加えずに行っ た未染色の等電点電気泳動ゲルを $5 \mathrm{~mm}$ の等閒 隔に切断し, それらを $1 \mathrm{ml}$ の脱イオン水にて 1

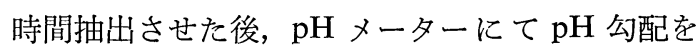
測定し, 各バンドに対応する $\mathrm{pI}$ 值を算定した. その $\mathrm{pI}$ 值は $\mathrm{E} 4=6.00, \mathrm{E} 3=5.90, \mathrm{E} 2=5.80$ であ った.これらの值は既報の成績とほぼ一致した ${ }^{2)}$. 遺伝的表現型の分類は，E4 のバンドの有無と， デンシトメーターで測定し得られた E 2/E 3 の比 をもとにして, Table 1 のごとく分類した ${ }^{4)}$.さ らにE $2 / \mathrm{E} 3$ の比が 1 前後のものには，12\%の polyacrylamide を支持体とした SDS 2 次元電気 泳動 ${ }^{5)}$ を行い，遺伝的表現型を同定した (Fig. 3). 


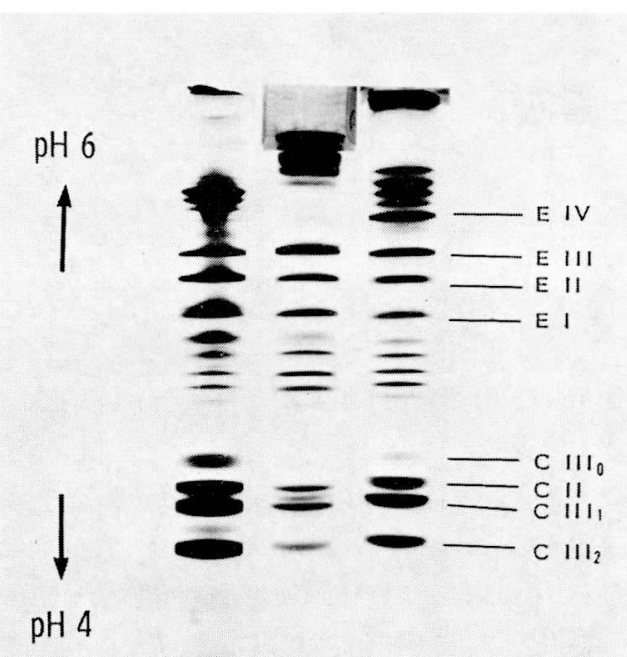

$E 3 / 2 \quad E 3 / 3 \quad E 4 / 3$

Phenotype

Fig. 1 Isoelectric focusing of apo VLDL.

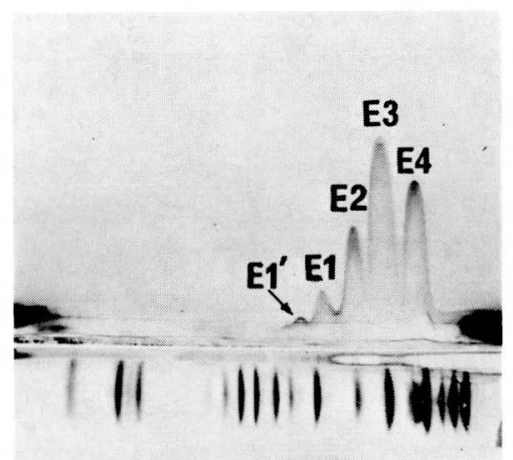

Fig. 2 Crossed immunoelectrophoresis of apo E.

pH6.0 $\leftarrow$ Isoelectric focusing $\rightarrow$ pH4.0

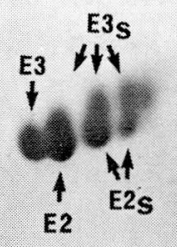

Fig. 3 Two-dimentional electrophoresis of apo E.
Table 1 Identification of phenotypes

\begin{tabular}{cc}
\hline Phenotype & Band of IEF gel \\
\hline E $4 / 4$ & E $4(+)$, E $4 \gg$ E 3, E 2 \\
E $3 / 3$ & E $4(-)$, E $2 /$ E $3<1$ \\
E $2 / 2$ & E $4(-)$, E $2 /$ E $3>1$ \\
E $4 / 3$ & E $4(+)$, E $2 /$ E $3<1$ \\
E $4 / 2$ & E $4(+)$, E $2 /$ E $3>1$ \\
E $3 / 2$ & E $4(-)$, E $2 /$ E $3>1$
\end{tabular}

Table 2 Frequency of phenotypes

\begin{tabular}{ccc}
\hline Phenotype & No. & Frequency $(\%)$ \\
E $4 / 4$ & 0 & 0 \\
E $3 / 3$ & 66 & 72.5 \\
E $2 / 2$ & 0 & 0 \\
E $4 / 3$ & 17 & 18.7 \\
E $4 / 2$ & 0 & 0 \\
E $3 / 2$ & 8 & 8.3 \\
\hline
\end{tabular}

Table 3 Gene frequency of apoprotein E

\begin{tabular}{cccl}
\hline Gene & Present study & Utermann & Zannis \\
\hline$\varepsilon 4$ & 0.09 & 0.14 & 0.11 \\
$\varepsilon 3$ & 0.87 & $0.77 * *$ & $0.72 * *$ \\
$\varepsilon 2$ & 0.04 & $0.09 *$ & $0.17 * *$ \\
${ }^{*} \mathrm{p}<0.05$ & $* * \mathrm{p}<0.01$ & &
\end{tabular}

総コレステロール，トリグリセライドおよび HDL-C はそれぞれネスコート TAC (日本商事), $\mathrm{TG}$ キット GN (日本商事), HDL-C セット(第一 化学)にて測定した. またアポ蛋白 (A-I, B, E) は, われわれの研究室で作製した抗血清を用いてロク ット免疫電気泳動法で測定した ${ }^{6)}$.

\section{III. 結 果}

\section{1.アポ $\mathbf{E} の$ 遺伝的表現型}

今回行った健常者 91 名のアポ $\mathrm{E} の$ 遺伝的表現 型の割合は，E 4/3 が17名 $(18.7 \%)$, E 3/3 が66名 $(72.5 \%), E 3 / 2$ が 8 名 $(8.3 \%)$ となり, E 4/4, E 4/2 およびE 2/2 は認められなかった (Table 2). この 成績を欧米の Utermann ${ }^{7)}$ やZannis ${ }^{8)}$ らのものと 比べると，E $3 / 3$ が多く逆に E 3/2 が少ないように 思われた，そこでこのことを遺伝子頻度の面から 検討してみると, $\varepsilon 4=0.09, \varepsilon 3=0.87, \varepsilon 2=0.04$ と なり，推計学上 Utermann やZ Zannis らのものと 比べ $\varepsilon 3$ が有意に高く $(\mathrm{p}<0.01)$, 一方 $\varepsilon 2$ は有意に 
Table 4 Serum lipid levels

\begin{tabular}{cccc}
\hline Phenotype & T. Chol. & T. G. & HDL-C. \\
\hline E $4 / 3$ & $203 \pm 33$ & $114 \pm 46$ & $58 \pm 12$ \\
E $3 / 3$ & $194 \pm 31$ & $112 \pm 44$ & $55 \pm 11$ \\
E $3 / 2$ & $191 \pm 25$ & $137 \pm 54$ & $52 \pm 13$ \\
\hline
\end{tabular}

Mean \pm SD $\quad(\mathrm{mg} / \mathrm{d} l)$

Table 5 Serum apoprotein levels

\begin{tabular}{cccc}
\hline Phenotype & apo A-I & apo B & apo E \\
\hline E $4 / 3$ & $112 \pm 17$ & $84 \pm 23$ & $6.2 \pm 1.5$ \\
E $3 / 3$ & $117 \pm 20$ & $77 \pm 23$ & $6.8 \pm 2.6$ \\
E $3 / 2$ & $112 \pm 32$ & $76 \pm 24$ & $7.4 \pm 2.6$ \\
\hline
\end{tabular}

Mean \pm SD $\quad(\mathrm{mg} / \mathrm{d} l)$

低かった $(\mathrm{p}<0.05$ vs. Utermann, $\mathrm{p}<0.01$ vs. Zannis). しかし， $\varepsilon 4$ につては推計学上もこれら のものとの閒には有意差を認めなかった (Table 3)。

\section{2. 各表現型別にみた血清脂質およびアポ蛋白 濃度}

各表現型別の血清脂質レベルは Table 4 に示し たごとく, 総コレステロール, トリグリセライド および HDL-C のいずれも各表現型の間には推計 学的な有意差は認められなかったが，トリグリセ ライドは E 3/2 群において他の群より高い傾向が みられた。 またアポ蛋白濃度も各表現型別にみて みたが, アポ A-I B, E のいずれもこれらの群の間 に推計学的な有意差を認めなかった (Table 5).

\section{IV. 考案}

原発性 III 型高脂血症患者の血中アポ $\mathrm{E}$ 濃度の 高值は Havel らにより報告されていたが9)，1975 年 Utermann らによる等電点電気泳動を用いた 研究によりアポEには isoprotein が存在するこ とが明らかになり，また原発性 III 型高脂血症に おいてはE 3 と E 4 が欠損していることが報告さ れた. その後 Utermann や Zannisらにより，こ の isoprotein の遺伝様式が明らかにされた ${ }^{7,10)}$. すなわち，E 2, E 3, E 4 に対応する，それぞれ $\varepsilon 2$, $\varepsilon 3, \varepsilon 4$ の 3 つ対立遺伝子が想定され, これらの 対立遺伝子の組み合せによる 6 種類の遺伝的表現 型が存在することが示された.さらにアポEの 各 isoprotein のアミノ酸配列も解明され ${ }^{11)}$ ，これ
らアポ E isoprotein の receptor-binding における 差異も明らかにされた ${ }^{12)}$.

最近，アポ $\mathrm{E} の$ 各表現型別の血中脂質レベルを

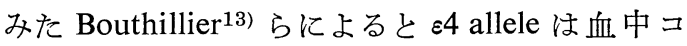
レステロールや LDL コレステロール濃度を上昇 させる dominant gene であるとされており，一方 $\varepsilon 2$ は VLDL コレステロールとトリグリセライド を上昇させる ressesive gene と報告されている。 さらに，V型高脂血症やアルコール性高脂血症で は $\varepsilon 4$ の頻度が有意に高いとの報告もみられてい るなど ${ }^{14,15)}$, III 型高脂血症以外においてもアポ $\mathrm{E}$ の遺伝的表現型と脂質代謝との関連性が示唆さ れてきている.

今回われわれは健常者におけるアポ $\mathrm{E}$ の遺伝子 頻度を求め, さらに各表現型別の血清脂質レベル およびアポ蛋白レベルとを検討してみた。その結 果はすでに報告されている. Utermann やZannis らのものと比べ, $\varepsilon 3$ が推計学的に有意に高く, 逆に 82 は有意に低かった. しかし, 84 について は有意差は認めなかった。このことは，本邦にお けるアポEの遺伝子頻度は欧米のものと比べると いくぶん異っていることを示唆しており，人種差 もしくは地域差があるものと考えられる。また E $2 / 2$ の $1 \%$ 程度に原発性 III 型高脂血症がみられ ると言われているが，本邦におけるこの疾患の頻 度が欧米より低いということも ${ }^{16)}$, 今回の $\varepsilon 2 か ゙$ 少ないといらことは矛盾しないように思われる.

次に, 今回検討を行った91名における血中コレ ステロール，トリグリセライド，HDL-C の值を 各表現型別に比較検討を行ったところでは推計学 的な有意差は認められなかった. しかし， $\varepsilon 2$ を含 むE 3/2 群においてトリグリセライドがいくぶん 高い傾向にあった。 また，各表現型別にみた血中 アポ A-I, B, E 濃度も血清脂質濃度と同じく各群 間に推計学的な有意差は認められなかった. 以上 の成績からアポ $\mathrm{E} の$ 表現型の差は今回検討し得た E 4/3 E 3/3, E 3/2 の各型においては血清脂質, ア ポ蛋白レベルに大きな影響をおよぼしていないも のと考えられた.

\section{V. 結 果}

健常者に扮けるアポ蛋白 $\mathrm{E}$ の遺伝的表現型の解 
析を行ったところ， $\varepsilon 3$ allele が欧米の報告より有 意に高く, 逆に $\varepsilon 2$ allele が有意に低いといら結果 を得た。このことからアポ $\mathrm{E} の$ 遺伝子頻度には人 種差があると考えられた。 また，各表現型別にみ た血清脂質およびアポ蛋白レベルでは，トリグリ セライドが, E 3/2 群においてやや高い傾向を示 したが，推計学的に有意な差は見いだせなかった。

\section{文献}

1) Utermann, G., Hees, M. and Steinmetz, A.: Polymorphism of apolipoprotein $\mathrm{E}$ and occurrence of dysbetalipoproteinemia in man. Nature, 269: 604-607 (1977).

2) Warnick, G. R., Mayfield, C., Albers, J. J. and Hazzard, W. R.: Gel isoelectric focusing method for specific diagnosis of familial hyperlipoproteinemia type 3. Clin. Chem., 25: 279-284 (1979).

3) Reisner, A. H., Nemes, P. and Bucholtz, C.: The use of Coomassie Brilliant Blue G 250 perchloric acid solution for staning in electrophoresis and isoelectric focusing on polyacrylamide gels. Analytic Biochem., 64: 509-516 (1975).

4) Wardell, M. R., Suckling, P. A. and Janus, E. D.: Genetic variation in human apolipoprotein E. J. C. I., 23: 1174-1182 (1982).

5) O'Farrell, P. H.: High resolution two-dimentional electrophoresis of protein. J. Biol. Chem., 250: 4007-4021 (1975).

6) 古賀俊逑, 山本匡介, 藤井貞人：アポリポタンパク の分離と免疫化学的定量 “免疫実験操作法” 日本免 疫学会編：1691-1701 (1977).

7) Utermann, G., Langenbeck, U., Beisiegel, U. and Weber, W.: Genetics of the apolipoprotein E system in man. Am. J. Hum. Genet., 32: 339-347 (1980).

8) Zannis, V. I., Just, P. W. and Breslow, J. L.: Human apolipoprotein $\mathrm{E}$ isoprotein subclasses are genetically determined. Am. J. Hum. Genet., 33: 1124 (1981).

9) Havel, R. J. and Kane, J. P.: Primary dysbetalipoproteinemia; Predominance of a specific apoprotein species in triglyceride-rich lipoprotein. Proc. Natl. Acad. Scin. U.S.A., 70: 2015-2019 (1973).

10) Zannis, V. I. and Breslow, J. L.: Human very low density lipoprotein apolipoprotein $\mathrm{E}$ isoprotein polymorphism is explained by genetic variation and posttranslational modification. Biochem., 20: 10331041 (1981).

11) Rall, S. C. Jr., Weisgraber, K. H. and Mahley, R. W.: Human apolipoprotein E. J. Biol. Chem., 257: 4171-4178 (1982).

12) Weisgraber, K. H., Innerarity, T. L. and Mahley, R. W.: Abnormal lipoprotein receptor-binding activity of the human $\mathrm{E}$ apoprotein due to CysteineArginine interchange at a single site. J. Biol. Chem., 257: 2518-2521 (1982).

13) Bouthillier, D., Sing, C. F. and Davignon, J.: Apolipoprotein $\mathrm{E}$ phenotyping with a single gel method; application to the study of informative matings. J. Lipid Res., 24: 1060-1069 (1983).

14) Ghiselli, G., Schaefer, E. J., Zech, L. A., Gregg, R. E. and Brewer, H. B. Jr.: Increased prevalence of apolipoprotein $\mathrm{E} 4$ in type $\mathrm{V}$ hyperlipoproteinemia. J. C. I., 70: 474-477 (1982).

15）松島昭彦, 内藤周幸 : アルコール性高脂血症患者に おける VLDL 分画のアポ蛋白 $\mathrm{E}$, およびC の分析. 動脈硬化，10: 829-833 (1982).

16) 渡辺 彰, 馬㴊 宏, 竹田亮祐: 3 型一次性高りポ 蛋白血症. 日本臨床, 41: 1804-1809 (1984). 


\title{
Summary
}

\section{Plasma Levels of Lipids and Apoproteins Among Apoprotein E Phenotypic Groups}

\author{
Yasuhisa IMARI, Shunichi KogA and Hiroshi IBAYASHI
}

Third Department of Internal Medicine, Faculty of Medicine, Kyushu University, Fukuoka

The phenotypes of human apoprotein $\mathrm{E}$ were studied in 91 normolipidemic persons using isoelectric focusing method. Observed phenotypes and their frequencies were $\mathrm{E} 3 / 3=72.5 \%, \mathrm{E} 4 / 3=$ $18.7 \%$ and $\mathrm{E} 3 / 2=8.3 \%$. On this bases, gene frequencies were calculated: $\varepsilon 4=0.09 ; \varepsilon 3=0.87$; $\varepsilon 2=0.04$. In comparison with those reported by Utermann and Zannis, the frequency of $\varepsilon 3$ was significantly higher $(\mathrm{p}<0.01$ vs. Utermann and Zannis), and the frequency of $\varepsilon 2$ was lower ( $\mathrm{p}<$ 0.05 vs. Utermann, $\mathrm{p}<0.01$ vs. Zannis). This result was implied that there were racial differences in gene frequency of apoprotein E.

The mean levels of plasma cholesterol, triglyceride, HDL-cholesterol and apoproteins (A-I, B, E) were compared among phenotypes. The triglycerides concentration of phenotype $\mathrm{E} 3 / 2$ was somewhat higher than others, but the difference was not statistically significant. No significant differences were found in the levels of cholesterol, HDLcholesterol and apoproteins among phenotypes.

Key words: apoprotein E, phenotype, gene frequency, isoelectric focusing. 